\title{
Terretonin G, a new sesterterpenoid antibiotic from marine-derived Aspergillus sp. OPMF00272
}

\author{
Takashi Fukuda $^{1}$, Yuko Kurihara ${ }^{2}$, Akihiko Kanamoto ${ }^{2}$ and Hiroshi Tomoda ${ }^{1}$ \\ The Journal of Antibiotics (2014) 67, 593-595; doi:10.1038/ja.2014.46; published online 7 May 2014
}

Marine-derived microorganisms are known as producers of many structurally unique and strong-bioactive compounds, including clinical medicines and research reagents. ${ }^{1-4}$ During our screening for new metabolites from marine-derived fungi, one new sesterterpenoid, named terretonin G (1), was isolated from the culture broth of Aspergillus sp. OPMF00272 along with eight known natural products, terretonin (2), ${ }^{5-7}$ LL-S490 $\beta$ (3), ${ }^{8}$ methyl-3,4,5-trimethoxyl2-[2-(nicotinamide)benzamido]benzoate (4), ${ }^{9}$ territrem $\mathrm{B}(5),{ }^{10}$ aspernolid A (6), ${ }^{11}$ butyrolactones I (7) ${ }^{12}$ and $\mathrm{V}(\mathbf{8}),{ }^{13}$ and aspulvinone $\mathrm{J}(9)^{14}$ (Figure 1). This study describes the fermentation, isolation, structural elucidation and biological activity of $\mathbf{1}$.

The fungus Aspergillus sp. OPMF00272 was isolated from poriferan collected on Ishigaki island in Okinawa, Japan, in 2008. The strain was inoculated into a 500-ml Erlenmeyer flask containing $100 \mathrm{ml}$ seed medium $\left(2.0 \%\right.$ glucose, $0.2 \%$ yeast extract, $0.05 \% \mathrm{MgSO}_{4} \cdot 7 \mathrm{H}_{2} \mathrm{O}$, $0.5 \%$ polypeptone, $0.1 \% \mathrm{KH}_{2} \mathrm{PO}_{4}$ and $0.1 \%$ agar, $\mathrm{pH} 6.0$ ). The flask was shaken on a rotary shaker at $27^{\circ} \mathrm{C}$ for 3 days. The seed culture $(2.0 \mathrm{ml})$ was transferred in a $1000-\mathrm{ml}$ culture box containing $150 \mathrm{ml}$ production medium ( $5 \%$ oat meal, $0.2 \%$ yeast extract, $0.1 \% \mathrm{Na}$ tartrate, $0.1 \% \quad \mathrm{KH}_{2} \mathrm{PO}_{4}, \quad 0.8 \%$ Daigo authentic seawater, Nihon Pharmaceutical Co., Ltd., Tokyo, Japan). The fermentation was carried out at $27^{\circ} \mathrm{C}$ for 7 days under static conditions. The culture broth $(150 \mathrm{ml} \times 3)$ was extracted with ethanol $(450 \mathrm{ml})$ for $2 \mathrm{~h}$. After this extract had been evaporated to an aqueous solution, the residue was partitioned between water and EtOAc to yield the crude extract $(684 \mathrm{mg})$ after evaporation of the EtOAc fraction. This extract was dissolved in a small volume of chloroform, applied to a silica gel column ( $40 \mathrm{~g}, 3.4 \times 10 \mathrm{~cm}, 0.04-0.063 \mathrm{~mm}$; Merck, Darmstadt, Germany), and eluted stepwise with 100\% chloroform, 50:1, 10:1, 5:1 and 1:1 (v/v) chloroform-methanol and 100\% methanol (300 ml each). Terretonin G was observed in the fraction eluted with 50:1 chloroform-methanol. This fraction was further purified by reversedphase C-18 HPLC $(20 \times 250 \mathrm{~mm}$; PEGASIL ODS, Senshu Scientific Co., Tokyo, Japan) under the following conditions: solvent, $53 \%$ $\mathrm{CH}_{3} \mathrm{CN}$ water isocratic condition; flow rate of $8.0 \mathrm{ml} \mathrm{min}^{-1}$; UV detection at $210 \mathrm{~nm}$. Under these conditions, terretonin $\mathrm{G}$ was eluted as a peak with a retention time of $20.1 \mathrm{~min}$. This fraction was collected and concentrated to yield pure terretonin $\mathrm{G}(1.3 \mathrm{mg})$ as a colorless solid.

The physico-chemical properties of terretonin G (1) are summarized in Table 1. The molecular formula of $\mathbf{1}$ was established as $\mathrm{C}_{27} \mathrm{H}_{38} \mathrm{O}_{9}\left([\mathrm{M}+\mathrm{Na}]^{+} m / z 529.2411\right)$ on the basis of HI-ESI-MS measurement, indicating that terretonin $\mathrm{G}$ contained nine degrees of unsaturation. The IR spectrum of 1 showed characteristic absorption at 3467,1738 and $1713 \mathrm{~cm}^{-1}$, suggesting the presence of hydoxy and carbonyl moieties. The structure of terretonin G (1) was mainly elucidated by analysis of NMR spectra including $2 \mathrm{D}$ NMR. The ${ }^{13} \mathrm{C}$ NMR spectrum (in $\mathrm{CD}_{3} \mathrm{OD}$ ) showed 27 resolved signals, which were classified into eight $s p^{3}$ methyl carbons, three $s p^{3}$ methylene carbons, one $s p^{2}$ methylene carbon, four $s p^{3}$ methine carbons and 11 quaternary carbons including four carbonyl carbons (C-3, C-6, $\mathrm{C}-16$ and $\mathrm{C}-18$ ) (Table 2). Analysis of the ${ }^{1} \mathrm{H}-{ }^{1} \mathrm{H}$ COSY spectra revealed two partial structures $\mathrm{C}-1$ to $\mathrm{C}-2$ and C-9 to C-11 (Figure 2). The ${ }^{13} \mathrm{C}-{ }^{1} \mathrm{H}$ long range couplings of $2 J$ and $3 J$ observed in the ${ }^{13} \mathrm{C}-{ }^{1} \mathrm{H}$ HMBC experiments (Figure 2) gave the following information: (1) The cross peaks from $1-\mathrm{H}_{2}(\delta 1.75,2.20)$ to $\mathrm{C}-3(\delta 215.9), \mathrm{C}-5(\delta$ $63.8)$ and $\mathrm{C}-10(\delta 44.5)$, from $2-\mathrm{H}_{2}(\delta 2.23,2.85)$ to $\mathrm{C}-3$, from $5-\mathrm{H}(\delta$

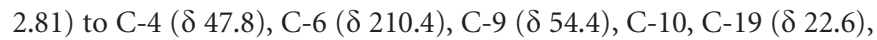
C-20 $(\delta$ 24.5) and C-22 ( $\delta$ 16.3), from 7-H $(\delta$ 4.12) to C-6, C-8 $(\delta$ $50.9), \mathrm{C}-14(\delta 57.6)$ and C-21 ( $\delta 12.4)$, from $9-\mathrm{H}(\delta 2.05)$ to $\mathrm{C}-8$ and $\mathrm{C}-10$, from $11-\mathrm{H}_{2}(\delta 2.45,2.61)$ to $\mathrm{C}-8, \mathrm{C}-12(\delta 150.7), \mathrm{C}-13(\delta 58.4)$ and $\mathrm{C}-23(\delta 111.5)$, from $14-\mathrm{H}(\delta 3.75)$ to $\mathrm{C}-7$ ( $\delta 85.9), \mathrm{C}-8, \mathrm{C}-9$, C-12, C-13, C-16 ( $\delta$ 209.7), C-21 and C-24 ( $\delta$ 22.6), from $19-\mathrm{H}_{3}(\delta$ $1.50)$ to $\mathrm{C}-3, \mathrm{C}-4, \mathrm{C}-5$ and $\mathrm{C}-20$, from $20-\mathrm{H}_{3}(\delta 1.07)$ to $\mathrm{C}-3, \mathrm{C}-4$, C-5 and C-19, from $21-\mathrm{H}_{3}(\delta 1.17)$ to C-7, C-8, C-9 and C-14, from $22-\mathrm{H}_{3}(\delta 1.15)$ to $\mathrm{C}-1, \mathrm{C}-5, \mathrm{C}-9$ and $\mathrm{C}-10$, from $23-\mathrm{H}_{2}(\delta 4.32,4.81)$ to $\mathrm{C}-11(\delta 29.1), \mathrm{C}-12$ and $\mathrm{C}-13$, and from $24-\mathrm{H}_{3}(\delta 1.52)$ to $\mathrm{C}-12$, C-13 and C-14 supported the partial structure I. (2) The cross peaks from $25-\mathrm{H}_{3}(\delta 1.58)$ to $\mathrm{C}-16, \mathrm{C}-17(\delta 83.3)$ and $\mathrm{C}-18(\delta 174.5)$ and from $18-\mathrm{OCH}_{3}(\delta 3.73)$ to $\mathrm{C}-18$ supported the partial structure II. (3) The cross peak from $15-\mathrm{OCH}_{3}(\delta 3.52)$ to $\mathrm{C}-15$ ( $\delta$ 173.0) supported the partial structure III. (4) The cross peaks from $14-\mathrm{H}$ to $\mathrm{C}-15$ and from $24-\mathrm{H}_{3}$ to $\mathrm{C}-16$ indicated that the partial structures I, II and III are connected as shown in Figure 2. Taking into consideration the

${ }^{1}$ Graduate School of Pharmaceutical Sciences, Kitasato University, Tokyo, Japan and ${ }^{2}$ OP BIO FACTORY Co., Ltd., Uruma Sandpit, Okinawa, Japan Correspondence: Professor H Tomoda, Graduate School of Pharmaceutical Sciences, Kitasato University, 5-9-1 Shirokane, Minato-ku, Tokyo 108-8641, Japan. E-mail: tomodah@pharm.kitasato-u.ac.jp

Received 23 October 2013; revised 22 March 2014; accepted 1 April 2014; published online 7 May 2014 


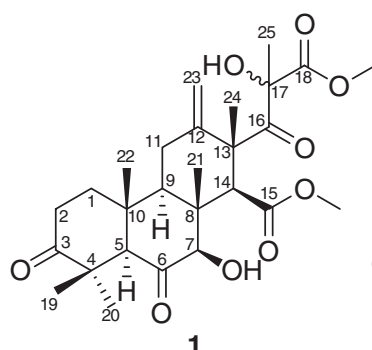

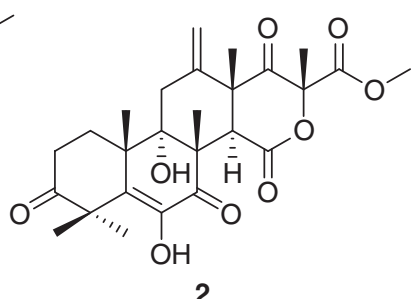<smiles></smiles><smiles>COC(=O)c1cc(OC)c(OC)c(OC)c1NC(=O)c1ccccc1NC(=O)c1cccnc1</smiles>

4

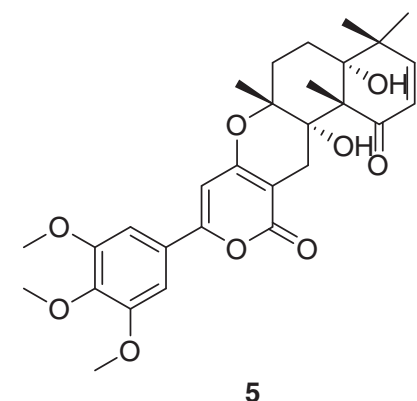<smiles>COC(=O)C1(Cc2ccc3c(c2)CCC(C)(C)O3)C=C(O)C(O)=C1c1ccc(O)cc1</smiles>

6<smiles>COC(=O)[C@]1(Cc2ccc(O)c(CC=C(C)C)c2)CC(=O)C(O)=C1c1ccc(O)cc1</smiles>

7<smiles>CC(C)=CCc1cc(C=C2OC(=O)C(c3cc(CC=C(C)C)c(O)cc3O)=C2O)ccc1O</smiles>

9

Figure 1 Structures of nine compounds produced by Aspergillus sp. OPMF00272. Terretonin G (1), terretonin (2), LL-S490ß (3), methyl-3,4,5-trimethoxyl2-[2-(nicotinamide)benzamido]benzoate (4), territrem B (5), aspernolid A (6), butyrolactones I (7) and V (8), and aspulvinone J (9).

Table 1 Physico-chemical properties of terretonin G

\begin{tabular}{lc}
\hline & Terretonin $\mathrm{G}$ \\
\hline Appearance & Colorless solid \\
{$[\alpha]_{6}^{6}$} & $4.2(c 0.1, \mathrm{MeOH})$ \\
Molecular formula & $\mathrm{C}_{27} \mathrm{H}_{38} \mathrm{O}_{9}$ \\
Molecular weight & 506 \\
HR ESI MS $\mathrm{m} / z$ & {$\left[\mathrm{M}+\mathrm{Na}^{+}\right.$} \\
Calcd & $529.2413\left(\right.$ for $\left.\mathrm{C}_{27} \mathrm{H}_{38} \mathrm{O}_{9} \mathrm{Na}\right)$ \\
Found & 529.2411 \\
$\mathrm{UV}(\mathrm{MeOH})$ & End absorption \\
$\mathrm{IR} v_{\max }^{\mathrm{KBr}}\left(\mathrm{cm}^{-1}\right)$ & $3467,1738,1713$ \\
\hline
\end{tabular}

molecular formula, the IR data and chemical shifts of C-7 $(\delta 85.9)$ and C-17 ( $\delta$ 83.3), a hydroxy moiety should be bound to both C-7 and $\mathrm{C}-17$. Thus, the planar structure of terretonin $\mathrm{G}$ was elucidated as shown in Figure 1.

The relative configurations of C-5, C-7, C-8, C-9, C-10, C-13 and C-14 were determined by NOE experiments. Observation of NOEs from $5-\mathrm{H}$ to $7-\mathrm{H}, 9-\mathrm{H}$ and $20-\mathrm{H}_{3}$, from $9-\mathrm{H}$ to $14-\mathrm{H}$, from $22-\mathrm{H}_{3}$ to
$19-\mathrm{H}_{3}$ and $21-\mathrm{H}_{3}$, and from $21-\mathrm{H}_{3}$ to $24-\mathrm{H}_{3}$ (Figure 3 ) indicated that they were assigned as $5 R^{\star}, 7 R^{\star}, 8 R^{\star}, 9 R^{\star}, 10 R^{\star}, 13 R^{\star}$ and $14 S^{\star}$. Stereochemistry of C-17, however, was not determined by NOE experiments.

The antimicrobial activity of $\mathbf{1}$ and $\mathbf{2}$ was investigated using our routine in-house assay system. ${ }^{15}$ From the antimicrobial assay using paper disk, 1 ( $20 \mu \mathrm{g}$ per $6 \mathrm{~mm}$ disk) showed antimicrobial activity with an inhibitory zone (10,8 and $8 \mathrm{~mm}$ ) against Gram-positive bacteria (Staphylococcus aureus FDA209P, Bacillus subtillis PCI219 and Micrococus luteus ATCC9341), but not against Gram-negative bacteria (Pseudomonas aeruginosa IFO12689 and Escherichia coli JM109) and fungi (Candida albicans ATCC64548 and Saccharomyces cerevisiae S288c). Interestingly, 2 (20 $\mu \mathrm{g}$ per $6 \mathrm{~mm}$ disk) showed no inhibitory activity against all microorganisms we tested.

Terretonin and its structurally related terretonins A-F have been reported; terretonin was reported as a mycotoxin ${ }^{5}$ and terretonins $\mathrm{E}$ and $\mathrm{F}$ were reported as inhibitors of the mammalian mitochondrial respiratory chain. ${ }^{7}$ Unfortunately, there has been no report about the biological activity of terretonins A-D. ${ }^{6}$ Accordingly, other biological activities of $\mathbf{1}$ in our in-house assays such as effect on cell cycle, ${ }^{16}$ lipid metabolites ${ }^{17}$ and alkaline phosphatase expression in myoblasts $^{18}$ were investigated. Unfortunately, 1 showed no 
Table 2 NMR spectroscopic data for terretonin $G$ in $C_{3} \mathrm{OD}$

\begin{tabular}{|c|c|c|c|}
\hline Position & $\delta_{H^{\mathrm{a}}}$ & $\delta_{C}{ }^{\mathrm{b}}$ & $\mathrm{HMBC}$ \\
\hline 1 & $\begin{array}{l}1.75, \mathrm{~m} \\
2.20, \mathrm{~m}\end{array}$ & 40.5 & $C-2,3,5,10$ \\
\hline 2 & $\begin{array}{l}2.23, \mathrm{~m} \\
2.85, \mathrm{~m}\end{array}$ & 34.6 & $C-1,3$ \\
\hline 3 & & 215.9 & \\
\hline 4 & & 47.8 & \\
\hline 5 & $2.81, \mathrm{~s}$ & 63.8 & $\mathrm{C}-4,6,9,10,19,20,22$ \\
\hline 6 & & 210.4 & \\
\hline 7 & $4.12, \mathrm{~s}$ & 85.9 & $\mathrm{C}-6,8,14,21$ \\
\hline 8 & & 50.9 & \\
\hline 9 & $2.05, \mathrm{dd}(J=14.0,3.0)$ & 54.4 & C-8, 10 \\
\hline 10 & & 44.5 & \\
\hline 11 & $\begin{array}{c}2.45, \mathrm{dd}(J=15.0,3.0) \\
2.61, \mathrm{~m}\end{array}$ & 29.1 & $C-8,9,12,13,23$ \\
\hline 12 & & 150.7 & \\
\hline 13 & & 58.4 & \\
\hline 14 & $3.75, \mathrm{~s}$ & 57.6 & $\begin{array}{c}\text { C- } 7,8,9,12,13 \\
15,16,21,24\end{array}$ \\
\hline 15 & & 173.0 & \\
\hline 16 & & 209.7 & \\
\hline 17 & & 83.3 & \\
\hline 18 & & 174.5 & \\
\hline 19 & $1.50, \mathrm{~s}$ & 22.6 & $C-3,4,5,20$ \\
\hline 20 & $1.07, \mathrm{~s}$ & 24.5 & $C-3,4,5,19$ \\
\hline 21 & $1.17, \mathrm{~s}$ & 12.4 & $C-7,8,9,14$ \\
\hline 22 & $1.15, \mathrm{~s}$ & 16.3 & $\mathrm{C}-1,5,9,10$ \\
\hline 23 & $\begin{array}{l}4.32, d(J=2.0) \\
4.81, d(J=2.0)\end{array}$ & 111.5 & $\mathrm{C}-11,12,13$ \\
\hline 24 & $1.52, \mathrm{~s}$ & 22.6 & $C-12,13,14,16$ \\
\hline 25 & $1.58, \mathrm{~s}$ & 27.0 & $\mathrm{C}-16,17,18$ \\
\hline $15-\mathrm{OCH}_{3}$ & $3.52, \mathrm{~s}$ & 51.7 & C-15 \\
\hline $18-\mathrm{OCH}_{3}$ & $3.73, \mathrm{~s}$ & 53.6 & C-18 \\
\hline
\end{tabular}

${ }^{a}$ Chemical shifts are shown with reference to $\mathrm{CD}_{3} \mathrm{OD}$ as $\delta 3.30$. ${ }^{b}$ Chemical shifts are shown with reference to $\mathrm{CD}_{3} \mathrm{OD}$ as $\delta 49.0$.

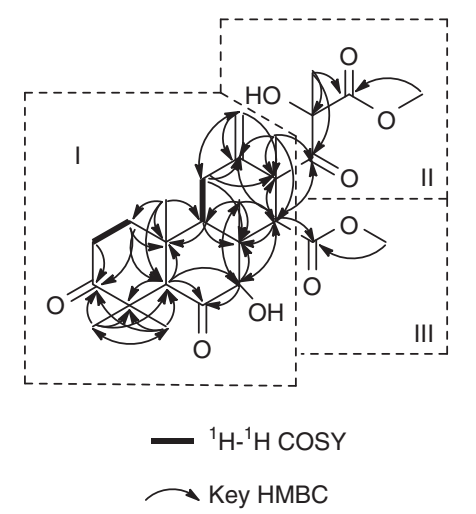

Figure 2 Key cross peaks observed in ${ }^{1} \mathrm{H}-{ }^{1} \mathrm{H}$ COSY and ${ }^{13} \mathrm{C}-{ }^{1} \mathrm{H}$ HMBC experiments of 1 .

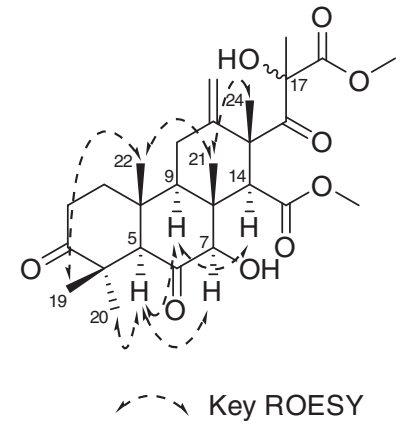

Figure 3 NOE experiments of 1 .

significant activity in these assays even at $25 \mu \mathrm{g} \mathrm{ml}^{-1}$ (data not shown). To our knowledge, this is the first report that terretonins showed antimicrobial activity.

\section{ACKNOWLEDGEMENTS}

We wish to thank Ms Nozomi Sasaki for excellent assistance throughout this work, and Ms Noriko Sato and Dr Kenichiro Nagai (School of Pharmaceutical Sciences, Kitasato University) for measurements of NMR spectra and MS data. This work was supported by JSPS KAKENHI Grant Number 25870704.

1 Blunt, J. W., Copp, B. R., Keyzers, R. A., Munro, M. H. G. \& Prinsep, M. R. Marine natural products. Nat. Prod. Rep. 30, 237-323 (2013).

2 Fenical, W. \& Jensen, P. R. Developing a new resource for drug discovery: marine actinomycete bacteria. Nat. Chem. Biol. 2, 666-673 (2006).

3 Feling, R. H. et al. Salinosporamide A: a highly cytotoxic proteasome inhibitor from a novel microbial source, a marine bacterium of the new genus Salinospora. Angew. Chem. Int. Ed. Engl. 42, 355-357 (2003).

4 Fukuda, T. et al. Structures and biosynthesis of the pyridinopyrones, polyenepyrones from a marine-derived Streptomyces Species. J. Nat. Prod. 74, 1773-1778 (2011).

5 Springer, J. P., Dorner, J. W., Cole, R. J. \& Cox, R. H. Terretonin, a toxic compound from Aspergillus terreus. J. Org. Chem. 44, 4852-4854 (1979).

$6 \mathrm{Li}, \mathrm{G}$. Y. et al. Sesterterpenoids, terretonins A-D, and an alkaloid, asterrelenin, from Aspergillus terreus. J. Nat. Prod. 68, 1243-1246 (2005).

7 López-Gresa, M. P. et al. Terretonins E and F, inhibitors of the mitochondrial respiratory chain from the marine-derived fungus Aspergillus insuetus. J. Nat. Prod. 72, 1348-1351 (2009).

$8 \mathrm{He}, \mathrm{J}$. et al. Cytotoxic and other metabolites of Aspergillus inhabiting the rhizosphere of Sonoran desert plants. J. Nat. Prod. 67, 1985-1991 (2004).

9 Wang, Y., Zheng, J., Liu, P., Wang, W. \& Zhu, W. Three new compounds from Aspergillus terreus PT06-2 grown in a high salt medium. Mar. Drugs 9, 1368-1378 (2011).

10 Ling, K. H., Yang, C. K., Kuo, C. A. \& Kuo, M. D. Solvent systems for improved isolation and separation of territrems A and B. Appl. Environ. Microbiol. 44, 860-863 (1982).

11 Parvatkar, R. R., D'Souza, C., Tripathi, A. \& Naik, C. G. Aspernolides A and B, butenolides from a marine-derived fungus Aspergillus terreus. Phytochemistry 70, 128-132 (2009).

12 Kitagawa, M. et al. Butyrolactone I, a selective inhibitor of cdk2 and cdc2 kinase. Oncogene 8, 2425-2432 (1993).

13 Lin, T., Lu, C. \& Shen, Y. Secondary metabolites of Aspergillus sp. F1, a commensal fungal strain of Trewia nudiflora. Nat. Prod. Res. 23, 77-85 (2009).

14 Haug-Schifferdecker, E., Arican, D., Brückner, R. \& Heide, L. A new group of aromatic prenyltransferases in fungi, catalyzing a 2,7-dihydroxynaphthalene 3-dimethylallyltransferase reaction. J. Biol. Chem. 285, 16487-16494 (2010).

15 Iwatsuki, M. et al. Lariatins, novel anti-mycobacterial peptides with a lasso structure, produced by Rhodococcus jostii K01-B0171. J. Antibiot. 60, 357-363 (2007).

16 Hagimori, K., Fukuda, T., Hasegawa, Y., Omura, S. \& Tomoda, H. Fungal malformins inhibit bleomycin-induced G2 checkpoint in Jurkat cells. Biol. Pharm. Bull. 30, 1379-1383 (2007).

17 Ohshiro, T. \& Tomoda, H. Isoform-specific inhibitors of ACATs: recent advances and promising developments. Future Med. Chem. 3, 2039-2061 (2011).

18 Fukuda, T. et al. Trichocyalides A and B, new inhibitors of alkaline phosphatase activity in bone morphogenetic protein-stimulated myoblasts, produced by Trichoderma sp. FKI-5513. J. Antibiot. (Tokyo) 65, 565-569 (2012). 